Somerville, (Sir) William

Some problems of reafforestation.

$S D$
409
$S 6$





\title{
SOME PROBLEMS
}

\author{
OB
}

\section{RE-AFFORESTATION}

Digitized by the Internet Archive

IV suvingooz with funding froms:

Microsoft Corporation

,

\section{LIBRAR}

rMOUITY OF FURESIRY

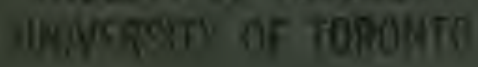

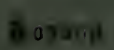

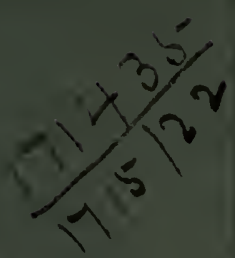

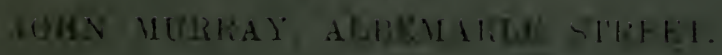
$192 \%$. 


$$
\frac{\pi D}{56}
$$




\section{SOME PROBLEMS OF RE-AFFORESTATION.}

No figures are available to show what area of British woodlands has been cleared during the war, but it is common knowledge that felling has been much in excess of normal, while planting operations have perforce been largely suspended. 'Timber of all kinds has been in demand, but the inroads have undoubtedly been greatest in the case of conifers, and owners of poorly-grown immature Scots pine, spruce, and larch have had an opportunity to realise, at a good price, timber which in pre-war times was practically unsaleable.

Whether the Government will take steps to secure the replanting of denuded areas remains to be seen, but in any case most owner's will want to re-invest a portion of the sum realised from sales, so that the next few years are likely to witness considerable silvicultural activity. Much has been learned in respect of economic forestry during the past twenty or thirty years, and it is well that the results of such experience should be applied to the problems of re-afforestation that lie ahead of us.

There are some who hold that a planter's choice of species should be confined to those which have been almost exclusively relied on in the past. As regards hard woods this decision is a sound one, and one cannot name a single exotic species of hard wood possessed of merits superior, or even equal to, those associated with native or long-acclimatized species. Our native oak, ash, elm, birch, sycamore, willow and poplar grow as fast, are as free from disease, and furnish as good timber as any exotic species of these genera that have been tried. In saying this it is not forgotten that Alnus incana possesses certain characteristics not shared by the common alder, Alnus glutinosa, inasmuch as it will grow quickly on poor thin chalky soil, and thus prove useful as a nurse to better species. Then, again, a number of exotic and hybrid poplars have been introduced during recent years, and some of them seem to possess great vigour in youth, but wliether in the end they will surpass 
long-tried species, such as the black Italian and the white poplars, cannot at present be determined.

While, therefore, planters are advised to adhere to the species of hard woods to which they are accustomed, the case is different in regard to conifers. In the past the planter's choice seldom went beyond Scots pine, Norway spruce, and European larch, with the occasional inclusion of silver fir and Corsican pine, and even less frequently of Weymouth and Maritime pines. This statement refers to plantations established thirty or more years ago, and is also limited to forestry on a commercial scale, and has no reference to ornamental planting. But although not planted on a large scale, enough has been done with certain exotic conifers to warrant their taking an important place in present-day silviculture. The newer conifers whose merits entitle them to attention on economic grounds are, in the first instance, the Douglas fir, the Sitka spruce, and the Japanese larch; and, to a much less extent, Abies grandis, Tsuga Albertiana (=Mertensiana), Pinus insignis (=radiata), and Thuja gigantea (=plicata).

There are some who urge that native trees alone should be depended on for commercial afforestation, forgetting that such trees, for instance, as the common larch and spruce, are no more natives than those that have just been mentioned, the only difference being that they happened to be introduced somewhat earlier. The list of forest trees-that is, trees attaining to timber dimensions-strictly indigenous to this country is a very short one. Of conifers, there are only the Scots pine and yew; while of hardwoods there are the sessile and pedunculate oaks, the beech, the ash, the wych elm, the birch, the alder, the aspen and the cherry.

The Douglas Fir.-Introduced from North-West America in 1828, this tree has been extensively planted in parks and arboreta. It has also been used to a certain extent in mixed plantations, and there are a few examples of pure woods of this species up to sixty years of age. The only two objections that can be urged against the Douglas fir are, first, that it does not thrive well upon a soil containing a high percentage of lime, and second, that, in exposed situations, its top and branches are apt to be broken by wind. As regards its antipathy to lime it may be said that an instance has recently been described ${ }^{1}$ which shows that even on the most pronouncedly calcareous soil of all, namely chalk, fair success has been obtained with Douglas fir. The surface. however, was covered to a depth of 2 or 3 inches with the accumulated leaf mould of a former crop of beecll. As to the frequency with which the top is

1 Quarterly Journal of Forestry, Vol. xi., 1917, pp. 1 and 189. 
broken by wind, it may be remarked that this loss generally occurs either in the case of solitary trees, or of trees thinly scattered throughout a wood. The Douglas fir usually grows faster than any species with which it may be mixed, and its top is therefore much exposed to the influence of gales. If, however, this species is grown in pure woods, one tree shelters another, and, except along the margin of the plantation, or on a hillside fully exposed to the south-west gales, the disadvantage referred to is not serious.

These drawbacks are much more than counterbalanced by the many merits possessed by this tree. In quality the wood is much superior to Scotch pine or spruce ; in fact, in point of durability it closely approaches larch, which it also resembles in colour and texture. In some parts of Scotland, before the war, a good deal of Douglas fir up to fifty years old was being put on the market, merchants often buying it at the price of Scots pine and spruce. On being asked as to the uses to which it was put, a forester remarked that it went into the sawmill as Douglas fir, but it all came out as larch post and rails!

Not only is Douglas fir timber of the highest value for general estate purposes, but it also furnishes excellent pit wood, and, when of sufficient size, it is unsurpassed for all high-class structural purposes. Its merits have now been thoroughly recognised in the timber trade, and Douglas fir-or Oregon pine, as it is often called-now takes a very high place in the lumber industry of the United States and Canada.

But, high as is the quality of the timber of this species, the volume of timber produced per acre is even more remarkable. Volume xx. of the Journal of the Board of Agriculture for 1913-14 contains the results of measurements of six plantations of pure Douglas fir in Scotland; England, and Wales, and the following is an abstract of the principal facts obtained.

\begin{tabular}{|c|c|c|c|c|c|c|c|}
\hline Estate & County & Age & $\begin{array}{c}\text { Mean } \\
\text { beight } \\
\text { of } \\
\text { dominant } \\
\text { crop }\end{array}$ & $\begin{array}{c}\text { True } \\
\text { volume } \\
\text { per acre } \\
\text { over } \\
\text { bark }\end{array}$ & $\begin{array}{c}\text { Value } \\
\text { per } \\
\text { cubic } \\
\text { ft. }\end{array}$ & $\begin{array}{c}\text { Value } \\
\text { of } \\
\text { standing } \\
\text { crop } \\
\text { per acre }\end{array}$ & $\begin{array}{l}\text { Average } \\
\text { annual } \\
\text { growth in } \\
\text { volume } \\
\text { per acre } \\
\text { in } \\
\text { cub. ft. }\end{array}$ \\
\hline Taymount. & Perth & 52 & $\begin{array}{l}\mathrm{Ft}_{\text {. }} \\
88\end{array}$ & $\begin{array}{c}\text { Cub. ft. } \\
8,460\end{array}$ & $\begin{array}{l}d \\
5 \frac{1}{3}\end{array}$ & $\begin{array}{c}£ \\
188\end{array}$ & 163 \\
\hline Lochwillan. & Carnarvon & 58 & 101 & 14,110 & 6 & 353 & 243 \\
\hline Llandinam. & Montgomery & 28 & 66 & 7,960 & $4 \frac{1}{5}$ & 139 & 284 \\
\hline Tortworth & Gloucester & 43 & 97 & 9,320 & 6 & 233 & 217 \\
\hline Do. & Do. & 29 & 66 & 4,700 & 4 & 78 & 162 \\
\hline Dunster & Somerset & 33 & 74 & 6,350 & 6 & 159 & 192 \\
\hline
\end{tabular}

From the year of planting these six woods have given an average annual growth in volume of $162 \mathrm{cub}$. ft. per acre as a 
mimimum and 284 cub. ft. as a maximum. To appreciate the full significance of these figures we must compare them with the yield of other conifers grown under average conditions. Thus, Scots pine grown on average land will have done well if, at fifty years, it shows a total growing stock per acre of 2,500 to 3,000 cub. ft. (true volume), the corresponding figures for Norway spruce being 3,500 to $4,000 \mathrm{cub}$. ft. In the former case the average aniual increment is $55 \mathrm{cub}$. $\mathrm{ft}$., and in the latter $75 \mathrm{cub}$. ft., so that even the least productive of the Douglas fir plantations has given three times as much yield as an average Scots pine wood, while the best has produced more than five times as much timber.

It may confidently be asserted that no tree is capable of furnishing such a high yield per acre as Douglas fir, and it should therefore be extensively planted wherever the conditions are at all favourable.

Sitka Spruce.-This is a tree whose native habitat is confined to the bottoms of the valleys on the Pacific seaboard of Canada and the United States. Introduced into Britain in 1831, it has been extensively planted, for the most part as specimen trees, in many districts. At Durris in Aberdeenshire it has proved superior to all other species at an altitude of $1,000 \mathrm{ft}$., and it has also given an excellent account of itself on land too wet and too peaty to suit most trees. On hot, thin, dry chalk in Sussex I find that the Sitka spruce is as promising as any species, but the woods are too young to warrant a final judgment as to its success under these trying conditions.

There being no pure woods of Sitka spruce of any considerable extent in this country it is impossible to quote acreage volume figures, as in the case of the Douglas fir, but both in height and in volume it surpasses the common spruce. Mr. Crozier, who has had unusual opportunities for studying the growth of the Sitka spruce in Scotland, states ${ }^{2}$ that this tree has grown at an altitude of 750 to $800 \mathrm{ft}$., in a mixed plantation, so much faster than the common spruce that before the seventeenth or eighteenth year the latter species had been largely overgrown and suppressed. At this age the Sitka spruces were 46 to $50 \mathrm{ft}$. in height, as compared with $35 \mathrm{ft}$. for the tallest specimens of the common spruce. He gives it as his opinion that Sitka spruce, in pure woods, and assuming favourable conditions, should yield $6,000 \mathrm{cub}$. ft. per acre of timber (quarter girth measure) at thirty-one years, and $10,000 \mathrm{ft}$. by the fifty-fifth year. Such yields compare not unfavourably even with those of Douglas fir. In the same

1 The green or Vancouver variety should alone be employed; the grey or Colorado variety is in all respects much inferior.

2 Trans. Roy. Scot. Arb. Suc., Vol. xxiii., p. 12. 
volime of the Transactions of the R.S.A.S. Mr. H. M. Cadell, drawing on his experience up to an altitude of $550 \mathrm{ft}$. in Stirlingshire, states that the Japanese larch and Sitka spruce have grown about equally fast and have far outstripped all the otlier species. In Vol. xxviii. of the same Transactions, Mr. A. C. Forbes expresses the opinion "that the value of Sitka spruce for planting on the exposed sites and wet soils which occupy so large a proportion of the surface of Ireland can scarcely be over-estimated."

While the timber is inferior in respect of clurability to that of the Douglas fir, it is at least as valuable as that of the common spruce, and under the name of the Silver Spruce it has a very high reputation for the construction of aeroplanes. The name Silver Spruce-not to be confounded with silver fir-is derived from the silvery or glaucous appearance of the foliage, a fact which gives the tree a high decorative value.

When grown singly the Sitka spruce forms strong side branches, and under these circumstances the stem is very coarse and knotty. It should therefore be planted fairly close, and thinning should not start till somewhat late, and should be moderate in extent. In woods of similar density it is said to clean itself better than coinmon spruce and is much more resistant to wind.

The Japanese Larch.-This species was introduced in 1861 , and there are now many pure plantations up to twenty years of age. Possibly this tree will not in later life attain to the dimensions of the European larch, but in the first twenty to thirty years it almost invariably surpasses the common larch both in height and in volume per acre. In quality of timber there is no appreciable difference between the two species, but there are certain other points of distinction to be noted. As compared with the common species, the Japanese larch has stronger side branches, and the stem is scarcely so straight. These are characteristics in which it is inferior; but, on the other hand, it grows much faster in youth, suppresses ground vegetation much more completely, forms a denser layer of humus, is practically immune to disease, grows on a wider range of soils - on poor chalk it is much superior-and recovers from such an injury as snow-breaking much more quickly and completely. It is also more decorative than the common larch, its foliage being longer and more silvery, while its young branches are of a warm cinnamon brown colour. There are few finer sights in nature than a young wood of Japanese larches when the ground is covered with snow, against which the young shoots make a very striking show of colour.

For a short rotation, designed for the supply of pit props or light fencing material, no species of tree can excel the Japanese 
larch, and as a nurse, to be removed when about twenty years old, it is of high value.

Mr. C. P. Ackers in Vol. vi. of the Quarterly Journal of Forestry draws attention to the inferior power of resistance of the Japanese larch in Gloucestershire to the excessive drought of 1911. In the North of England in the same year it was little affected, and his conclusion is that " the Japanese larch promises to become a far more useful tree than the European, and to give a crop of useful timber where the European could never pay."

The possibilities of the Japanese larch are well shown in the report of the Judges on the Competition of Plantations in Yorkshire in connection with the Royal Agricultural Society's Show at Doncaster in 1912. ${ }^{1}$ At the age of ten years the First Prize plantation, at an altitude of 800 to $850 \mathrm{ft}$., had an average height of 17 to $18 \mathrm{ft}$., with a girth in the middle of the stem of 8 to $10 \mathrm{in}$. There was no trace of disease, and the accumulation of leaf mould on the surface of the ground, combined with complete suppression of surface growth, was very remarkable. In the Quarterly Journal of Forestry for July, 1917, Mr. W. B. Havelock gives certain measurements of trees in a wood of Japanese larch at Brocklesby, Lincolnshire. These were planted in January, 1900, and after seventeen years' growth the height was 40 to $45 \mathrm{ft}$., and the average girth at $5 \mathrm{ft}$. from the ground was $19 \mathrm{in}$.

Abies grandis.-This is perhaps the fastest-growing of the silver firs, and it is least affected by "Aphis," which makes the common silver fir so difficult to establish even under a shelter wood. All silver firs, however, are very sensitive to spring frost, and their growth in youth is slow, so that they are not so attractive from the commercial point of view as certain other genera of conifers. They all bear a large amount of shade, and are useful for underplanting. Their timber is inferior to that of the spruce, but, given suitable conditions, some of them, notably $A$. grandis, will give a much larger yield per acre.

The Western Hemlock, Tsuga Albertiana.(=Mertensiana), grows with great rapidity in most parts of the country, provided the soil is not calcareous. It is much superior to the Canadian hemlock ( $T$. canadensis), which seldom retains a good leader, and is apt to take the form of an overgrown bush. The Western hemlock, on the other hand, has a particularly straight stem, and although its leading shoot is apparently so delicate it is rarely broken by the wind. The timber may be classed with spruce.

R.A.S.E. Journal, Vol. 73, 1912, p. 220. 
Pinus insignis (- radiata) is not hardy enough for general planting, but in the south and south-west of England, in the south-west of Scotland, and over a large part of Ireland, especially near the coast, it grows with great vigour, and in a short time, forms a large quantity of timber, not, however, of the highest quality. $\quad \mathrm{Mr}$. B.W. Adkin has given some figures as to the relative rate of growth of this tree. In Cornwall, near Newquay, in a mixed plantation the common spruce averaged $3 \mathrm{ft}$. in girth, Scotch pine $3 \mathrm{ft}$. 4 in., Spanish chestnut $2 \mathrm{ft}$. $S$ in. to $3 \mathrm{ft}$, and $P$. insignis $5 \mathrm{ft}$. $4 \mathrm{in}$, to $5 \mathrm{ft} .8 \mathrm{in}$. In a wood near Penzance $P$. pinaster girthed $2 \mathrm{ft}$. to $3 \mathrm{ft}$. and $P$. insignis $3 \mathrm{ft}$. to $4 \mathrm{ft}$. "In Hampshire also the $P$. insignis have quite double as fast a growth as larch, though the larch grows to perfection." At Muckross, near Killarney, in a wood 45 years old " the larch are undoubtedly fine, but the pine ( $P$. insignis) is nearly double the diameter of the larch, and no doubt contains three or four times as much timber." 1

Thrija gigantea (= plicata), the Red Cedar of Western Canada, is held in high esteem by certain planters in this country. It is quite hardy, grows fast, is highly decorative, and yields fine red durable timber, which, in the tree's native country, is chiefly used for shingles, a purpose at present of no account in this country. There is a mixed wood of $T$. gigantea and Douglas fir on the estate of Benmore, Argyllshire, planted in the winter of 1876-77. In 1911 the Douglas fir averaged about $70 \mathrm{ft}$. in height, and T. gigantea $10 \mathrm{ft}$. less. A sample area was measured in that year," there being 890 stems per acre, half of which were Douglas fir and half $T$. gigantea. "The volume of timber per acre, according to quarter-girth measurement to $5 \mathrm{in}$. diameter, deducting $1 \mathrm{in}$. for bark, is as follows :-Douglas fir, $5,000 \mathrm{cub}$. ft. per acre, and $T$. gigantea $2,430 \mathrm{cub}$. $\mathrm{ft}$. per acre. This gives a total of 7,430 cub. $\mathrm{ft}$. per acre, and although the Douglas fir has proved much superior to the other, the yield of $T$. gigantea compares favourably with that of many other species." 3

The Corsican Pine (Pinus laricio) with its varieties, the Taurian and Calabrian, is not a new species, having been introduced into this country over 150 years ago, but it is one whose merits deserve wider recognition. On strongish land, and on thin chalk, it grows much better than any other pine, and furnishes timber, which, though somewhat coarser than Scots

1 Quart. Journ. For., Vol. vi., p. 13.

${ }^{2}$ D. K. M'Beath, Trans. Roy. Sout. Arb. Suc., Vol. xxvii., p. 107.

'Since the above was written, a leaf disease (Keithia thujina) bas appeared in this country, and has proved very destructive in Ireland and in Sussex. It might therefore be well if planters were, for the prescnt, to hold their hand in respect of this spccies. 
pine, is equally suitable for general purposes. To appreciate the possibilities of this tree one should see it growing at such a place as Cissbury Rings on the South Downs, some four miles from the sea north of Worthing. Fully exposed to the southwest gales, and on the poorest calcareous soil, trees forty to fifty years old are making a height growth of $1 \frac{1}{2} \mathrm{ft}$, a year, their growth being much superior to other species with which they are associated.

Other conifers could be mentioned which have proved serviceable under certain conditions. Thus the Weymouth Pine has given a very large yield on poor healthy land in the south of England, but it is now so much affected by the white pine blister that its outlook is very uncertain. The white spruce (Picea alba) is reported to grow much better than larch or common spruce at an altitude up to $2,000 \mathrm{ft}$. near the Cumberland and Northumberland boundary, ${ }^{1}$ and it is largely depended on for afforesting the barren heaths of the Danish coast, but it is probable that the Sitka spruce would, as a rule, give superior results.

A few years ago plants of such species as Douglas fir, Japanese larch, and Sitka spruce were quoted in most nursery catalogues at a price that prohibited their use except for ornamental purposes. There is no reason why they should cost appreciably more than Scots pine, common spruce or larch, and now that there is an extensive demand for them nurserymen are raising them in large quantities and offering them at reasonable prices. If, however, a planter contemplates extensive afforestation with any of the species suggested, it would be well to look three or four years ahead, and make a contract at a definite price with a nurseryman, who would thus be able to make favourable terms for the necessary seed, and the plants would ultimately be forthcoming at the lowest possible cost. Or the planter may procure the seed and raise the plants in a home nursery, but success in nursery treatment postulates conditions of soil and management that are not al ways forthcoming.

A good deal of experimental work has been done of recent years which goes to show that forest trees, whose natural habitat embraces a wide area, have developed varietal characters, and that much of the success of planting may depend on whether one has been fortunate to secure the right variety for any particular locality. The Scots pine, for instance, is distributed over the greater part of Europe and a large portion of. Asia, and if seed be obtained from, say, Scotland, Sweden, France, and Switzerland, it will be found that the resultant plants show very different characters in regard to rate and

1 A. C. Forbes, Royal Commission on Coast Erosion and Afforestation, Vol. ii., p. 196. 
habit of growth and resistance to disease. In this country Scots pines raised from Scottish seod ("native Scotch") give the best results, and many nurserymen have had the experience of burning large "breaks" of pines raised from continental seed, because the plants were so unhealthy as to be unsaleable. Probably such a tree as the Douglas fir, distributed as it is over an inmense area in Western America, has also several varieties, indeed two-the Oregon and Colorado-have long been known. Of these, the green (Oregon) variety is by far the better for general purposes, but even this variety may have -in fact is known to have-sub-varieties which vary in value for British conditions. The whole subject is of great importance and should be thoroughly investigated. Meanwhile planters must depend on their judgment in selecting plants by appearance, unless they collect their own seed, in.which case healthy well-grown parent trees should alone be utilised.

A inistake, too oiten made in the past, should be avoided in future, namely, complicated and irrational mixtures of species. There is, no doubt, a good deal to be said for certain inixtures, where one species is deep-rooted and thus gives support to solne shallow-rooted species, or where the ground vegetation is suppressed by a dense-crowned species to the advantage of its light-crowned neighbour. But the difficulties of management are considerably increased when one has to regard the requirements of two kinds of tree in place of one, and the problem becomes almost baffling where there are perhaps half a dozen species equally distributed over the whole area. Often, in the past, the main purpose of a mixture seems simply to have been based on a desire to add variety to the woodland; or it may have been the result of uncertainty as to whether some species or other would succeed on the area. Again, the mixture may have had for its object the production of an early return through the agency of thinnings, as, for instance, where the larch has been used to "nurse" up some species, such as oak, of little value as young timber. This is quite a legitimate purpose, provided too much is not sacrificed in its attainment, but unless the removal of the nursing crop is attended to betimes it may do a great deal more harm than good. A mixture, much in vogue at one time, which looked attractive on paper, but was really opposed to sound principles, consisted in planting about 200 oaks or other hardwoods per acre at, say, $15 \mathrm{ft}$. intervals, and filling up the ground with some nursing species which were designed to be gradually removed, leaving the oaks to form the final crop. The fallacy of such a mixture consists in this-that it gives no opportunity to select the best formed and most vigorous individuals to constitute the final crop. Under such a system every oak planted 
must be retained till the end of the rotation, whereas if 1,000 oaks had been planted in the first instance 800 inferior individuals would have been removed in the course of the rotation, and the 200 retained till the end would certainly comprise larger and finer stems. This argument would necessarily be greatly strengthened if the wood were planted pure in the first instance, containing, as it would do, three or four thousand plants; and still more so if it had been established by artificial sowing or by natural. regeneration, when perhaps there might have been fifty to a hundred thousand seedlings from which to make the selection of 200 as the main crop. One has only to examine a pure wood of any species to realise how great is the difference in individual characteristics. Broadly speaking, the greater the number's the greater is the opportunity for selecting high-class stems to form the final crop.

While it is desirable to emphasise the importance of this consideration it is not necessary to push the idea to the extent that one finds in some countries. Thus in some forests in Denmark beeches are planted not as single trees but in bunches of five to fifteen, so that instead of having three or four thousand from which to select, one has five to fifteen times that number. ${ }^{1}$ But if this extreme is bad the other, which allows little if any opportunity for selection, is worse.

While the Douglas fir and spruces are generally best grown in pure woods, or, at least in pure groups, there are often advantages in growing such trees as the oak and larch in association with beech. If the land is of a good class for oak this tree will grow well alone, but if the soil is thin, rather light, and dry, much better growth of the oak will be secured by a mixture with beech. Very fine oaks are to be found thinly scattered in beech woods on the Chilterns, Cotswolds, and other limestone areas. Similarly as regards larch, which often reaches its largest dimensions on quite shallow soil if nourished by beech humus. But larch is such a profitable crop, even when of quite moderate dimensions, that, as a rule, it may be planted pure. In making this suggestion it is not forgotten that the common larch is sometimes severely attacked by disease, but it is rare that at the age of twenty to thirty years more than 50 per cent. of the stems are attacked. and infection after that age is unusual, and in no case serious. It is on this fact that the Novar system of combating larch disease is based. On Sir Ronald Munro-Ferguson's estate of Novar, in Easter Ross, the larch is planted alone, and at the age of sixteen to twenty years all diseased and inferior stems are removed, 
three to five hnndred of the best being retained to grow on. Before the war these thinnings realised 20l. to 25l. per acre. At this stage the wood is underplanted with Douglas fir, Sitka spruce, Abies grandis, Thuja gigantea, Western hemlock, beech or some other species which will establish itself and grow up under the mild shade of the larch. It is intended to thin the larch again when about forty years old, leaving at that time 100 to 200 trees per acre to grow into heavy timber. At the end of the rotation (sixty to eighty years) both the larch and underwood will be felled, or the underwood be left to grow on till it also is mature. ${ }^{2}$

In regard to initial density of stocking-that is, number of trees planted per acre-it may be said that in the period immediately before the war there was a distinct reaction from the very close planting (about 6,000 plants per acre) that was strenuously advocated twenty years ago. As in so many cases the question is largely one of circumstances. If one is dealing with two-year-old seedlings, costing, say, $8 s$. per 1,000 when planted, one can afford to make a more liberal use than if one is employing four-year-old plants, possibly pitted, costing, it may be, $2 l$. or $3 l$. per 1,000 when in their final position.

An extra thousand trees planted per acre will only affect the very earliest thinnings, and if there is no local demand for small stuff it may not pay to take it out. Of course one gets a complete canopy a year or two earlier by close planting, but if the planting of an extra thousand trees costs $1 l$. per acre one must receive $2 l$. nett per acre more for the thinnings at the eighteenth year if, apart from any problematical benefit to the main crop, one is to secure 4 per cent. on the outlay. Whatever the number of trees that may be planted on Scots pine land of the best class there will only be room for some 1,400 by the twentieth year. Planted $4 \mathrm{ft}$. by $4 \mathrm{ft}$. in triangles, 3,144 trees are required to stock an acre, whereas, with interspaces $3 \mathrm{ft}$. by $3 \mathrm{ft}$. the number is 5,590 . In the former case 1,744 would theoretically have come out as thinnings, in the latter case 4,190; but it may easily happen that the larger individual size of the smaller number may make them the more valuable.

Besides the local market, other factors that should influence one's judgment in regard to density of stocking are $(a)$ the quality of the situation, (b) the rate of growth and character of the particular species, (c) the presence or absence of rank herbage. The poorer the soil the smaller is the average size of each tree, and therefore the larger the number for which there is room. Trees that grow rapidly in youth, like larch, Douglas fir, poplars, \&c., need not be so close planted as slower growing 
species, like oak, spruce, silver fir, \&c. If the young plants have to contend with strong herbage-or, indeed, with any prejudicial factor, such as rabbits, or insects-greater density in the stocking is justified, if only to discount a higher death rate. Trees, again which readily lose their side branches, e.g., larch, need not be crowded to the extent necessary with species, e.g., spruce, whose lower branches must be killed when very young if the stems are to clean themselves properly. For general purposes, and assuming the trees set out in triangles, a distance of $4 \mathrm{ft}$. from plant to plant may be taken as the standard, which means, theoretically, 3,144 trees per acre. An additional foot of interspace reduces the number of trees to 2,012 per acre, and such wide planting is quite justifiable in the case of good ground and a quick-growing species, where small thinnings are of low value.

In the past the great majority of woods have suffered from over-thinning, nor has it been sufficiently recognised that a degree of density right for one species may be wrong for another. The main results of over-thinning are (1) the growing stock is not at its maximum, and consequently the highest annual increment cannot be secured, and (2) the trees are encouraged to retain their branches, and this means shorter boles and coarser and more knotty timber. Attention has, in many cases, been given too much to the individual trees, forgetting that in commercial forestry it is the yield of the wood as a whole, not the vigour of the single trees, that determines success.

Where woods are primarily designed as shelter-belts a degree of thinning that would be excessive under other circumstances is not only justifiable but necessary. Here the intention is to provide shelter to fields lying to leeward, and this object will be better secured by trees with low-reaching branches than by clean stems with small crowns confined to the upper third or fourth of their length. Moreover, such trees, being better balanced and better rooted, are not so liable to be blown down or broken over, and a shelter-belt, as its name implies, is generally formed in an exposed situation where stability is vital to success. Similarly along the windward side of a wood, thinning should begin earlier and be carried further. On that side of the wood, too, deep-rooted species and those which, given space, will produce and retain strong side branches should be employed. Such trees are the beech, oak, silver fir and Corsican and black Austrian pines. It is perhaps not generally recognised that the safety of a wood in regard to gales is largely dependent on the outer fringe of trees, and especially on the outermost row. The marginal trees should be encouraged to produce strong low-reaching branches 
on the windward side, for it is evident that these provide the best counterpoise to the pressure of the wind, and as long as they remain standing the rest of the wood is fairly secure. And yet. one sometimes sees such marginal trees severely pruned in an attempt to produce "clean " boles, the fact being overlooked that it is their very roughness which gives them their special value.

Replanting with conifers a cleared area of this class of tree is often disappointing on account of damage by insects, especially the Pine Weevil (Hylobius, abietis). This beetle breeds abundantly in the stools of recently felled pines, and in stems and strong branches that may be left for a year or two on or near the denuded area. From these breeding places it emerges to feed upon the bark of young conifers, and in the case of a severe infestation bardly a plant will escape. Much can be done to combat it by stripping the bark from the stools and exposed roots, and by timely removal or destruction of all top and lop. The insect may also be trapped by laying out inverted pieces of fresh coniferons bark, at least a foot square, from which the insects are collected and placed in widemouthed bottles, to be afterwards destroyed. When the weevils are most abundant, usually in May and the first half of June, the traps must be visited daily. Thereafter inspection every two or three days will suffice. The attractiveness of the lures is improved by placing some fresh sawdust underneath, and both the slabs and the sawdust should be renewed every fortnight or so. Twenty such traps per acre will account for large numbers of weevils. But concurrently with trapping the insects should be hand-picked from the stems and herbage, an eradicative method more effective even than trapping. A few pine stems left lying in a wood will also attract the insect for breeding purposes, and when the eggs have been laid, but before the weevils have emerged, these stems may be removed and sawn up for firewood or, if large enough, used for other purposes.

Until comparatively recently almost the only method of combating the pine weevil was to defer replanting for five or six years after a wood had been felled, during which time the old stools passed into a condition unsuitable for the breeding of the insect. But when the loss of growth during this period is considered, and also in view of the fact that rank weeds will have established themselves on the area, considerable expenditure on trapping and hand-picking, by making immediate re-stocking possible, is thoroughly justified.

School of Rural Economy,

W. SOMERVILLE. Oxford. 



\section{TENTH EDITION \\ (FIFTY-FIRST THOUSAND) \\ or \\ Elements of Agriculture \\ A TEXT-BOOK \\ PREPARED ONDER THE $\triangle$ UTHORITY OF THE}

ROYAL AGRICULTURAL SOCIETY OF ENGLAND.

BY W. FREAM, LL.D.

REVISED AND ENLARGED EDITION, EDITED BY

J. R. AINSWORTH-DAVIS, M.A. (Trin. Coll., Camb.),

Principal of the Royal Agricultural College, Cirencester, and Professor of Natural History in the University of Bristol.

CONTENTS.

PART I.-THE SOIL.

1. Formation of Soll.

2. Composition and Classification of Solls.

3. Physical Properties of Solls.

4. Sodrces of Loss and Gain to SoIls.

5. IMPROVEMENT OF SOILS.

6. AGRICULTURAL IMPLEMENTS.

7. TILLAGE.

8. Mandres and Mandring.

PART II. - THE PLANT.

9. SEEDS AND THEIR GerMination.

10 \& 11. Structure and Functions of Plants.

12. Cultivated Puants.

13. WEEDS.

14. Selection of SeEds.

15. Grass LaNd aNd its MaNagement.

16. FARM CroPS.

17. Hardt Froit Culture.

18. FUngus Pests.

PART III.-THE ANIMAL.

19. STRUCTURE AND FUNCTIONS OF FARM ANMMLLs.

20. Composition of the ANimal Body.

21. Foods AND Feeding.

22. Principles of BreediNG.

23. Horses: their BReeds, Feeding, and Management.

24. Cattle: thetr Breeds, Feeding, and MaNagement.

25. Sheep: their Breeds, Feeding, and Managhment.

26. Pigs: their Breeds, Feeding, and MaNagement.

27. The Fattening of Cattle, Sheep, and Pigs.

28. DAIRYING.

29. Podltry and Poultry Keeping.

30. HARMFUL AND BeNEFiotal ANIMALs.

INDEX.

or all Booksellers.

700 PAGES, WITH 333 ILLUSTRATIONS.

Price SEVEN SHILLINGS and SIXPENCE NETT, bound in cloth.

LONDON : JOHN MURRAY, 50A ALBEMARLE STREET, W.1. 
PUBLICATIONS OF THE ROYAL AGRICULTURAL SOCIETY OF ENGLAND. JOURNAL OF THE SOCIETY.

Now published as an Annual Volume of ahout 500 pages, in paper covers. Free to Members : Price to Non-Members, Ten Shillings.

TEXT-BOOK ON AGRICULTURE.

ELEMENTS OF AORICULTURE: \& Text-book prepared under the authority of the Royal Agricultural Society of England by the late W. FREAM, LL.D. Tenth (Revised and Enlarged) Edition (5lst Thousand), edited by J. R. AINSWORTH-DAVIS, M.A. 700 pp. with 333 Illustrations. 1918. Price 78.6d. nett, bound in cloth.

\section{FARM ACCOUNT BOOKS.}

No. 1. A DIARY, combining Cash Account with daily record of Farm Transactions. Price 48.

No. 2, A PARM ACCOUNT BO0K, 3nd Edition, showing payments and receipts, and supplying a form of Annual Balance Sheet. Price 8s.6d. Published for the Society and sold by Messrk. FORSTER, GROOM \& Co, Ltd., 15 Charing Cross, London. S.W.1.

No. 3, FARM CASH BOOK, receipts and payments, to be used with a Ledger. Price 10s, $6 d$.

No. 4. FARM LtDOEK giving specimen entries and particulars of proflt and loss account and balance sheet. Price $88.6 d$.

Nos. 3 ard 4 are to be obtained at the Society's House, 16 Bedford Square, London, W.C. 1.

\section{PAMPHLETS.}

VETERINART PAMPHLETS BY PROFESSOR SIR GEORGE BROWN, C.B.:

DENTITION AS INDICATIVE OF THE AGE OF FARM ANIMALS. Sixth Edition (1913). 64 pp. With 60 Illustrations. Price 18.

ANIMALS OF THE FARM IN HEALTH AND DISEASE, 72 pp. With 52 Illustrations. Fourth Edition (1909). Price 18.

THE STRUCTURE OF THE HORSE'S FOOT AND THE PRINCIPLES OF SHOEINO. 23 pp. Fourth and Enlarged Edition (1902). With 12 Illuatrations. Price $6 d$.

CONTAGIOUS FOOT ROT OF SHEEP. Second and Enlarged Edition (1905). 24 pp. With 8 Illustrations. Price 18.

OTHER VETERINARY PAMPHLETS :

THE MARE AND FOAL. By Professor J. WORTLEY AXE, M.R.C.V.S. 58 pp. With 20 Illustrations. Second Edition (1909). Price 18.

THE LAMBING PEN. BY HAROLD LEENEY. 3rd Ed.(1914), 40 pp. With 9 Illustrations. Price $6 \pi$.

TUBERCULOSIS AS REGARDS HEREDITY IN CAUSATION AND ELIMINATION FROM INFECTED HERDS. By PROFESSOR SIR JOHN MCFA X YeAN, M.B., B.Sc., C.M. (1911). 19 pp. Price 18.

CALF REARINo: An Experiment conducted at the Woburn Experimentai Farma. 1912-14. By J.AUGUSTUS VOELCKER, M.A., B.Sc., Ph.D., 1915. $12 \mathrm{pp}$. Price $6 d_{n}, 3 d$, to Members. PAMPHLETS BY MR. CHARLES WHITEHEAD, F.L.S., F.G.S.:

PRACTICAL HINTS ON FRUIT FARMING. (1904). With 10 Illustrations. 43 pp. Price l.

HOP CULTIVATION. With 13 Illustrations (1893). $46 \mathrm{pp}$. Price 18.

DATRY PAMPHLETS :

(Issued under the authority of the Datry Committee of the Soctety.)

THE PRACTICE OF (a) CHEDDAR, (b) CHESHIRE, \& (c) STILTON CHEESE.MAKING. Price $2 d$. each.

SIMPLE RULES FOR BUTTER-MiKINo. (Sheet.) Price ld. each, or 58. per 100 . Mounted on card and varnished, to hang up in the Dairy, $6 d$. each.

RECIPES FOR MAKING CREAM AND SOFT CHEESES. Price $1 d$.

RECIPE FOR MAKINO SCALDED CREAM. Price $1 d$.

MILK ADULTERATION. Price $1 d . ; 5$. per 100.

COMPENSATION FOR THE UNEXHATHER PAMPHLETS: FERTILISERS. By J. AUGUSTUS VoELCKER, M.A. B.Sc., Ph.D., and A. D. HALL, M.A. (1914). 16 pp. Price 18.

PRACTICAL HINTS ON VEOETABLE FARMINO. By JAMES UDALE (1904). With 15 Illustrations. $41 \mathrm{pp}$. Price 18.

THE WOBURN EXPERIMENTAL STATION OF THE ROYAL AGRICULTURAL SOCIETY OF ENGLAND. By J. AUGUSTUS VOELCKER. M.A., B.Sc., Ph.D. Annual Reports on Field, Feeding, and Pot-culture Experiments (1899-1917). Price 18. each.

REPORT ON THE WOBURN POT-CULTURE STATION. BY J. AUGUSTOS VOELCKER, M.A. B.Sc. Ph.D. With 17 Illustrations (1900). 52 pp. Price 28.6d.

THE MAKINo OF THE LAND IN ENGLAND. By ALBERT PBLL. (1899), 27 pp. Price $6 d$.

THE MANAOEMENT AND PLANTINO OF BRITISH WOODLANDS. By Profesgor CHARLES E. CURTIS, F.S.I. (1904). With 6 Illustrations. 36 pp. Price 18.

THE CONVERSION OF HOME.OROWN TIMBER. BY ROBERT ANDRRSON, F.S.I. (1904). With 4 Inlustrations. $28 \mathrm{pp}$. Price 18.

INSECTS INJURIOUS TO FOREST TREES. By CECIL WARBURTON, M.A. F.Z.S. (1904). With 7 Illustrations. $16 \mathrm{pp}$. Price 18 .

ORCHARD AND BUSH.FRUIT PESTS AND HOW TO COMBAT THEM. By CECIL WARBURTON, M.A. F.Z.S. With 12 Illustrations. Second Edition (1910). 20 pp. Price $6 d$.

THE DRYiNo OF FRUIT AND VEGETABLES. By J. A UGUSTUS VoELCKER, M.A., B.Sc., Ph.D. With 4 Illustrations (1897). $23 \mathrm{pp}$. Price $3 \dot{d}$.

COTTAGE SANITATION IN RURAL DISTRICTS. By H. MACLEAN WILSON, M.D. B.Sc. With a Preface by T. Pridgin TEale, F.R.S. Second and Enlarged Fdition. 32 pp. 12 Illustrations (1896). Price $3 d$. per copy: 2s. per doz.; 12s. $6 d$. per 100.

The above can be obtained at the Soctety's House, 16 Bedford Square, London, W.C.1., through any bookseller, or of Mfr. JOHN MURRAY, 50a Albemarle Street, W.1.

Coples of pumphlets sold at not less than One Shilling each are obtainable by Members of the Soclety at half-prtce on direct application to the Secretary.

\section{COLOURED DIAGRAMS.}

(Obtainable from Messrs. W. \& A. K. Johnston, Ltd.. Edina Works, Easter Road, Edtnburgh.) TWENTY.SIX DIAORAMS OP INJURIOUS INSECTS. Drawn from Nature by the late Miss GEORGIANA. E. ORM EROD, in conjunction with the late Miss ELEANOR A. ORMEROD. F.R.Met.Soc. Arranged in Five Sets, comprising (1) Common Insect Attacks; (2) Insects affecting Corn Crops and Grass: (3) Insects affecting Fruit Crops: (4) Insects affecting Roots and Gardens; (5) Insects affecting Trees. Also varnished and mounted on canvas, with rollers.

EIOHT DIAGRAMS REPRESENTINO THE LIFE.HISTORY OF THE WHEAT PLANT (after FRANCIS BAOER). With Explanatory Pam phlet hy W. UARRUTHERS, F.R.S.

THE POTATO DISEASE. By W. CARROTHER S, F.R.S. 

$\mathrm{SD}$

409

S6

Forestry

\section{Somerville, (Sir) William Some problems of re- afforestation}

\section{PLEASE DO NOT REMOVE} CARDS OR SLIPS FROM THIS POCKET
UNIVERSITY OF TORONTO LIBRARY

$$
[171435]
$$




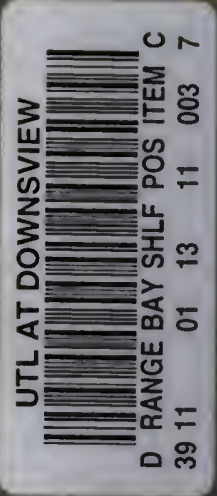

